\title{
THE ROLE OF THE COMMON AGRICULTURAL POLICY IN STIMULATING RURAL JOBS IN POLAND
}

\author{
Iwona Nurzyńska ${ }^{\varpi}$ \\ Institute of Rural and Agricultural Development, Polish Academy of Sciences
}

\begin{abstract}
This paper explores the role of the Common Agricultural Policy in creating non-agricultural jobs in rural Poland. The analyses were based on monitoring indicators of Rural Development Program 2007-2013 and public statistics. The paper argues that dynamic technological changes in agriculture require redefining the approach towards challenges related to the decreasing demand for human labor in agriculture. Although the CAP proves to have a positive impact on rural job creation in Poland, the results are a long way from meeting the needs. Therefore, this paper calls for a strategic re-orientation of CAP objectives and indicates the need for a more integrated policy which offers synergies with other types of EU and national public aid. Only such a policy mix can enable a more effective creation of quality jobs in rural areas.
\end{abstract}

Keywords: Common Agricultural Policy, rural labor, non-agricultural jobs, policy instruments

\section{INTRODUCTION}

Quality job creation, providing sound financial and social foundations for rural livelihoods, is at the core of regional development, labor market, economic competitiveness and rural development policies. The intervention measures provide financial and non-financial support to strengthen sustainable foundations of socio-economic growth and improve social and territorial cohesion. Structured around two pillars, the Common Agricultural Policy of the European Union offers synergies and may contribute to those objectives. This paper tackles the issue of barriers to rural entrepreneurship development and discusses the role of CAP measures in addressing those barriers. The author argues for the redesign of strategic objectives of the CAP and a tighter integration with other public policies in order to strengthen their role in the creation of quality rural jobs which, in addition to providing a sufficient remuneration, are also socially rewarded. This paper relies on the theoretical background of growth and development theories - especially including the New Growth Theory - and consists of three main parts. Section 1 presents the theoretical background which underlies the evolution of public policies addressing socio-economic development and job creation. Section 2 examines the quality of rural labor in Poland, believed to be a key barrier to the development of non-agricultural jobs. Section 3 attempts to evaluate the effects of CAP measures aimed at job creation and rural entrepreneurship development. The empirical analysis uses public statistical data, monitoring data collected during the implementation of CAP instruments and the results of the author's own and joint research on both the institutional barriers to rural entrepreneurship ${ }^{1}$ and the role of the CAP for Polish agriculture ${ }^{2}$.

${ }^{1}$ The research results regarding barriers to, and growth opportunities for, rural entrepreneurship are presented in: Nurzyńska et al., 2011 and Nurzyńska, 2013.

${ }^{2}$ The research was carried out by Nurzyńska, Drygas and Goraj in 2016-2017. The results are presented in the report by Nurzyńska et al., 2017. The research included an analysis of FADN data analysis and a survey with 150 family market-oriented farms in 5 voivodeships: Zachodniopomorskie, Pomorskie, Warmińsko-Mazurskie, Wielkopolskie and Kujawsko-Pomorskie.

$凶$ PhD Iwona Nurzyńska, Institute of Rural and Agricultural Development, Polish Academy of Sciences, 72 Nowy Świat St., 00-330 Warszawa, Poland, e-mail: iwona.nurzynska@gmail.com, https://orcid.org/0000-0002-3389-0359 


\section{HUMAN CAPITAL IN THE GROWTH PROCESS IN SELECTED THEORETICAL CONCEPTS}

Historically, technical progress allowed the non-farm sectors to absorb the "released" agricultural workforce. This was long true in Europe in the 1960s-1970s when the growth of manufacturing and service industries was strong enough to absorb the workforce moving out of farming. According to the analytical framework provided by Robert Solow in 1956, most of the economic growth comes from an increase in physical capital and labor which are subject to decreasing returns. The Solow's model assumed technology to be determined by forces external to the economy, and therefore is often referred to as an "exogenous" model of growth (Fagerberg, 1994). Neoclassical assumptions conclude that markets are generally highly competitive and usually lead to optimum production levels and optimum resource allocation patterns; they also imply that the governments are relatively limited in their capacity to promote economic growth otherwise than by encouraging market competition, providing adequate education and encouraging savings and investment (Mankiw and Taylor, 2016, p. 63-91). Over time, there has been a growing consensus across the literature of social sciences which contends that there are other factors which contribute more to economic growth than traditional factor endowments. The New Growth Theory challenges the neoclassical model, claiming that knowledge accumulation is assumed to be a productive input with increasing marginal productivity. Romer (1986) argues: "We now know that the classical suggestion that we can grow rich by accumulating more and more pieces of physical capital like fork lifts is simply wrong." Since then, economists have long stressed the importance of human capital to the growth process. One might even expect that ignoring human capital would lead to incorrect conclusions (Mankiw et al. 1992). The essential point of the New Growth Theory is that knowledge drives growth. Romer indicates that economies with lower levels of human capital achieve relatively lower economic growth rates. The latter can be improved through economic integration and collaboration among economies which provide conditions for flows of human capital and accumulation of technical knowledge (spillover effects). Human capital determines the scale of the technological gap which, in turn, conditions the pace and efficient use of technical knowledge spillover. As a result, investments in human capital are vital to the growth process (Romer, 1989). The quality of human capital fundamentally depends on education levels and affects the development of the national labor market and employment figures, especially in a knowledge economy. The development of growth theories also resulted in a rising interest in the importance of institutional factors and social capital. As Rodrik (2003) argues in the volume In Search of Prosperity: Analytic Narratives on Economic Growth, institutions refer to the quality of formal and informal sociopolitical arrangements ranging from the legal system to broader political institutions. As an endogenous growth factor, the institutions play an important role in promoting or hindering economic performance. Metainstitutions (property rights, the rule of law), the "playing field," and economic incentives are key for economic performance as they can facilitate or hinder collaboration, exchange and joint actions. "Good" and "proper" institutional structures may help set off disadvantages associated with remoteness and economic handicaps (Rodrik et al., 2002). The institutional network or "institutional thickness" of a given territory increases the potential for higher economic growth. As pointed out by Myrdal (1957) in his cumulative causation theory, adverse socio-economic developments tend to occur simultaneously in backward regions. These negative phenomena are interlinked and, in a long run, lead to social exclusion and marginalization. Even if underdeveloped regions offer the advantage of low-wage labor, these benefits tend to be offset by agglomeration economies found in industrialized regions.

Most rural areas in Poland can be classified as backward regions, except for the group located near large cities (Nurzyńska, 2016b). Myrdal argues that underdeveloped regions may benefit from growth in developed regions through "spread" effects resulting from the diffusion of innovations into a lagging region. However, these benefits tend to be offset by the "backwash" effects which mean the outflow of capital and labor from the lagging region to the developed region (Dawkins, 2003 , p. 139). For the backward rural areas, it is difficult - if not impossible without external intervention - to embark on the growth path. However, without the mobilization of existing endogenous local capacity, the external support might not be enough to overcome the development barriers. Rodrik argues that "governments are constrained by limits on their resources - financial, 
administrative, human, and political. They have to make choices on which constraints to attack first and what kind of reforms to spend political capital on. What they need is $(\ldots)$ an explicitly diagnostic approach that identifies priorities based on local realities" (Rodrik, 2007, p. 5). Employment performance depends on the opportunities offered by the local economy, the supply of skilled human capital, as well as local government policies supported by national labor market institutions and regulations (European..., 2016). Both the EU Cohesion Policy and the Common Agricultural Policy are based on the principle of financial solidarity between the rich regions and the poor ones but at the same time, they are driven by the choice of priorities and best value for money ${ }^{3}$.

\section{FACTORS INFLUENCING RURAL LABOR MARKET IN POLAND}

Over the past few decades, many European countries have witnessed a significant decrease in the farming population due to continued decline in farm incomes and changes to socio-economic structures of EU rural areas. In 2005-2014, there was a reduction by almost $25 \%$ in agricultural labor input in the EU-28 (European..., 2015; Ploeg van der, 2008). In Poland, the number of people working in agriculture decreased from $25 \%$ of the total number of employees in 1989 to $11.5 \%$ in 2014. Poland has been experiencing the emergence of the "new rural economy" which affects the development of the rural socio-economic fabric (shift away from agricultural employment). As a consequence, in 2016, over $70 \%$ of the rural population were not involved in farming (Halamska, 2013, p. 91-103).

The effective deployment of labor can be described by the employment rate. In general terms, there are no considerable differences in economic activity (measured by the employment rate ${ }^{4}$ ) between the Polish urban and rural population: in 2014, the rate was low and amounted to $50.9 \%$. At the same time, significant statistical differences in economic activity exist within the rural population itself. In 2014, the employment rate among

\footnotetext{
${ }^{3}$ In Poland, financial solidarity is exemplified by the fact that in 2007-2013 Poland was the largest beneficiary of both the RDP and the Cohesion Policy. As the less developed country, Poland received the largest part of Cohesion funds of all EU member states.

${ }^{4}$ People aged 15 or more.
}

the rural dwellers employed in farming was $63.5 \%$; for the population not involved in farming (referred to as "landless"), that rate was $44.2 \%$. Family employment is the key difference between the farming and non-farming population. In the group of rural employees not involved in farming, market employment relations prevail (Frenkel, 2016, p. 17-51).

Family employment is accompanied by low levels of labor productivity. This is exemplified by the fact that merely $30 \%$ of those solely employed in agriculture meet the criteria of full-time employment ${ }^{5}$. This indicates the scale of hidden unemployment in the Polish agriculture, which is also reflected by the differences in unemployment rates between the farming and rural population (Fig. 1). In 2015, the unemployment rate in the farming and non-farming population was $4.4 \%{ }^{6}$ and $9.7 \%$, respectively.

The empirical data proves that the employment rate depends on educational background: the higher the education level, the higher the employment rate. In 2014, the employment rate among the rural population with tertiary, secondary and primary education was $77.9 \%$, $61.6 \%$ and $17.7 \%$, respectively. Despite significant improvements over the last decade, the education level of the Polish rural population continues to be considerably lower compared to urban residents: $1 / 4$ of the rural population only have a basic level of education (Frenkel, 2016). Thus, it can be stated that the key to improve the employment rate of the landless is the increase in educational levels. Education, along with skills and experience specific to a given economic activity, constitute the main qualitative characteristics of human capital. The graph (Fig. 2) below shows the complexity of and interdependencies between various factors which influence the economic activity in general while particularly affecting the rural areas. These elements constitute the entrepreneurial ecosystem.

\footnotetext{
${ }^{5}$ Working 2120 hours or more per year, i.e. 265 days a year, 8 hours a day (Annual Work Unit). Others are part-time workers, including those (more than 50\%) working merely on a half-time basis. It should also be noted that in all those years, especially during the systemic transformation in the 1980s-1990s, the Polish agricultural sector functioned as a social buffer absorbing the redundant workforce from industrial sectors going through deep restructuring processes.

${ }^{6}$ In reality, a considerable part of the formally employed in agriculture find alternative non-agricultural sources of income, often in the informal economy.
} 


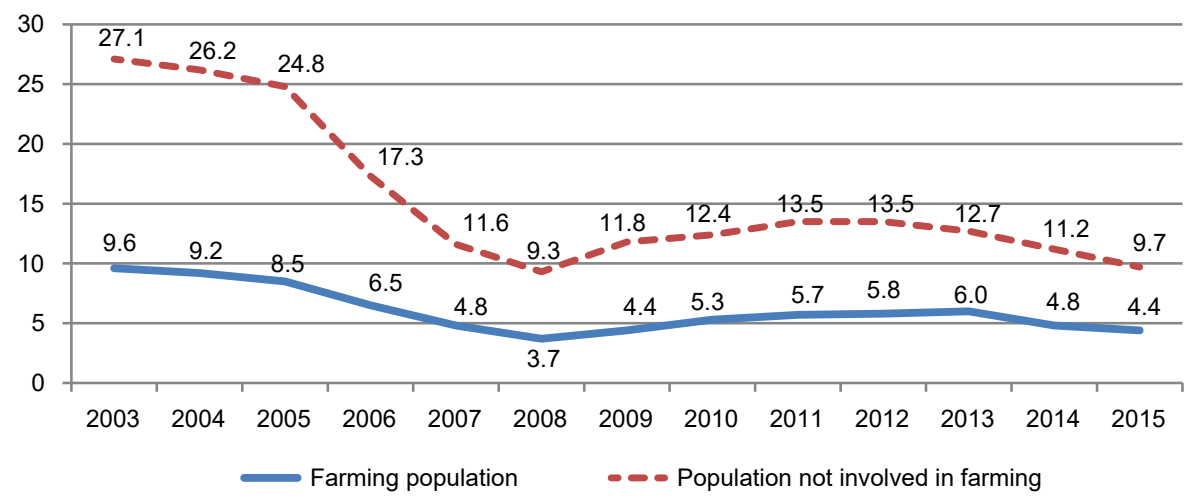

Fig. 1. Unemployment rate of the "landless" and farming population in rural areas in 2003-2015

Source: own elaboration based on Central Statistical Office data.

The entrepreneurial institutional ecosystem can facilitate or hamper business development and job creation. Public policies, access to investment sites, technical infrastructure and business support institutions - responsible for providing training, advice, information and financial services - play a key role in such a system. As pointed by Rodrik (2003), institutions refer to the quality of formal and informal sociopolitical arrangements ranging from the legal system to broader political institutions. As an endogenous growth factor, institutions play an important role in promoting or hindering economic performance. The system's fundamental elements are human and social capital. Institutional economists argue that the selection of "good institutions" enables the development of a proper institutional framework stimulating growth and innovation (Farole et al., 2009; Wilkin, 2005). An effective support system contributes to overcoming peripheral disadvantages and poor natural endowments (Acemoglu et al., 2004; Rodrik, 2003). Also, the Public Choice Theory delivers the proof that rent-seeking or ineffective institutions may adversely affect economic performance.
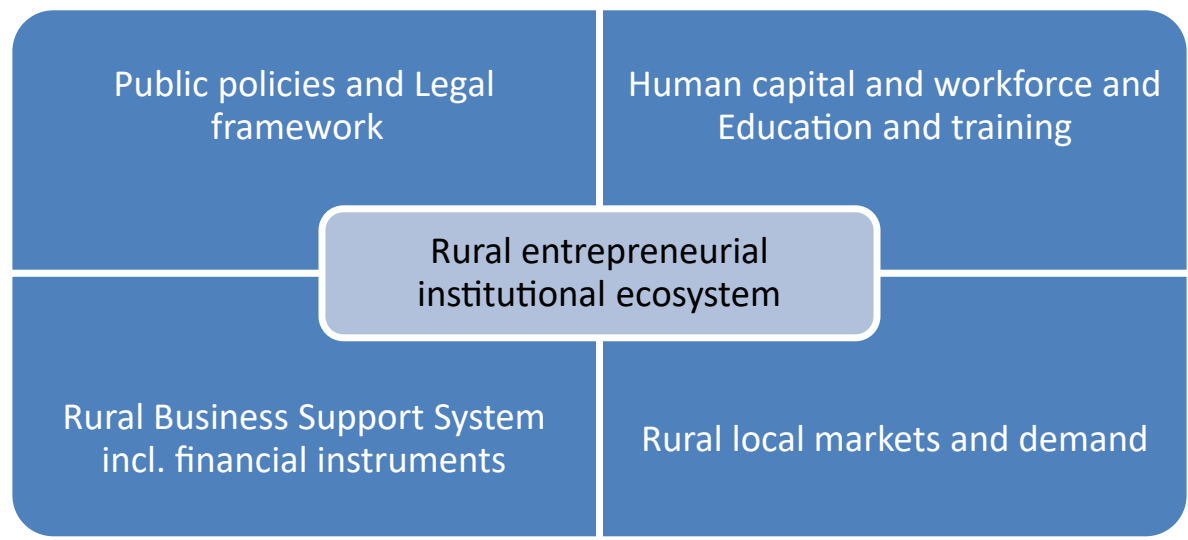

Fig. 2. Rural entrepreneurial institutional ecosystem which affects economic activity in rural areas

Source: own elaboration. 


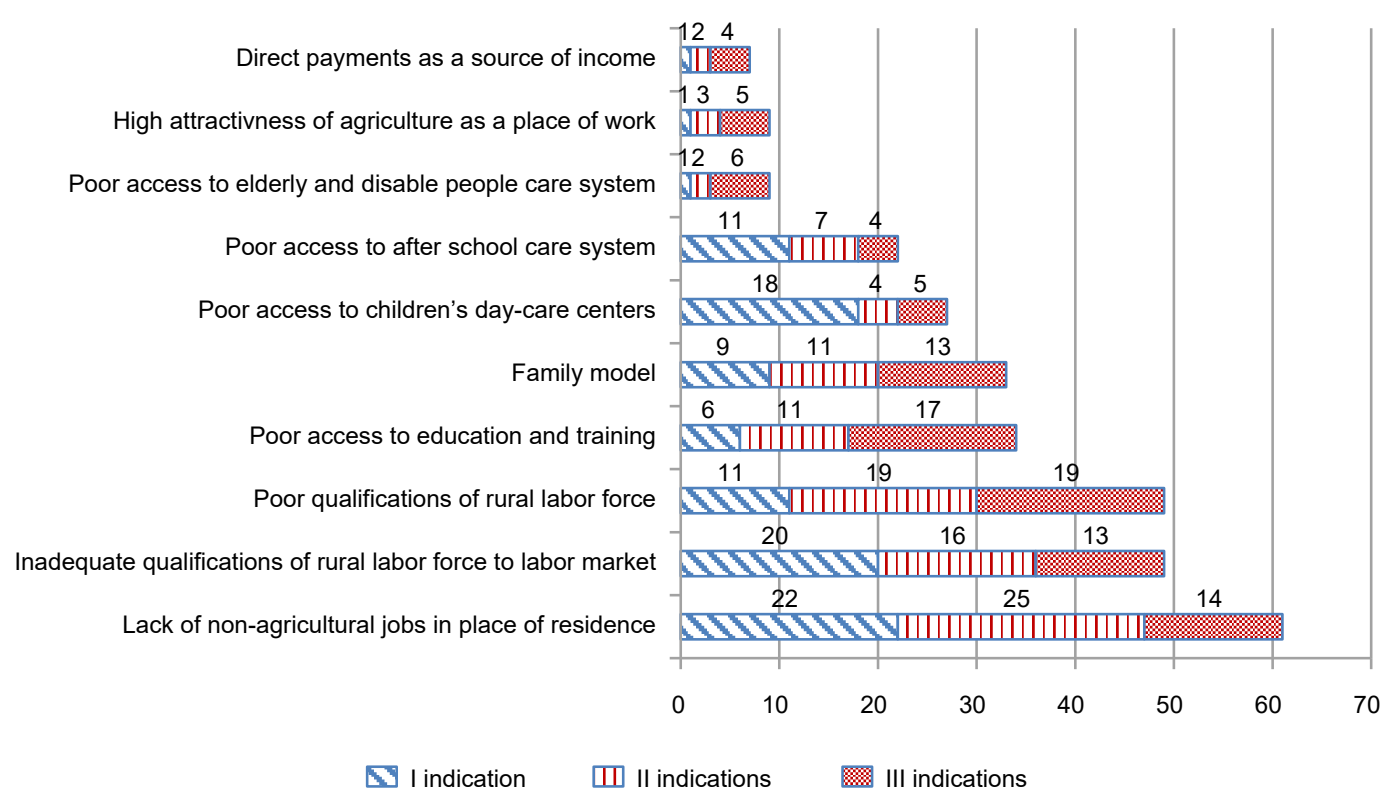

Fig. 3. What are the main 3 barriers to development of non-agricultural rural activities? (\% of indications, $\mathrm{N}=1,500$ )

Source: own work based on the report Polska wieś..., 2015, p. 171.

The empirical research carried out by the author ${ }^{7}$ allows indicating some key barriers to entrepreneurship development, which are particularly relevant in the rural periphery, including: lower quality of rural human capital (education and qualifications); low concentration of labor resources which restricts access to specialists; lack of entrepreneurial models (attitudes, family model, cultural heritage); lower level of social capital (trust, collaboration); inadequate legal environment (as regards non-financial and regulatory matters) of small rural businesses; low demand and income disparity in rural areas; growth patterns; lower quality of technical infrastructure (roads, Internet, energy access); poor access to financial infrastructure and instruments; inadequate training and lack of professional business advisory services; poor targeting of business support which does not match the needs of rural entrepreneurs.

The analysis of barriers indicates that public intervention in the field of institutional framework, which facilitates economic activity and enables a more effective use of rural labor resources, is indispensable. The purpose of a targeted external intervention shall be to stimulate rural endogenous capacity, including human

\footnotetext{
${ }^{7}$ See also reference 1.
}

capital quality. The annual survey with 1500 rural inhabitants, organized by the Polish Ministry of Agriculture and Rural Development, showed that the rural inhabitants themselves believe their poor or inadequate skills to be the key barrier to development of economic activity (Fig. 3).

\section{EFFECTS OF THE CAP ON RURAL JOB CREATION IN POLAND}

The EU public aid policy offers a wide range of instruments focused on: promoting entrepreneurship attitudes; improving the entrepreneurship ecosystem, including the regulatory framework; improved access to education and training (with emphasis on acquiring skills and qualifications); access to financial resources, including refundable financial instruments for start-ups and development of businesses; and the elimination of nonfinancial barriers to growth of small rural businesses. Following the adoption of Agenda 2000 and the establishment of the second pillar, the CAP became oriented on the improvement of living conditions and diversification of rural incomes. With new objectives of the Europe 2020 strategy for smart, sustainable and inclusive growth, both employment and job creation were put 


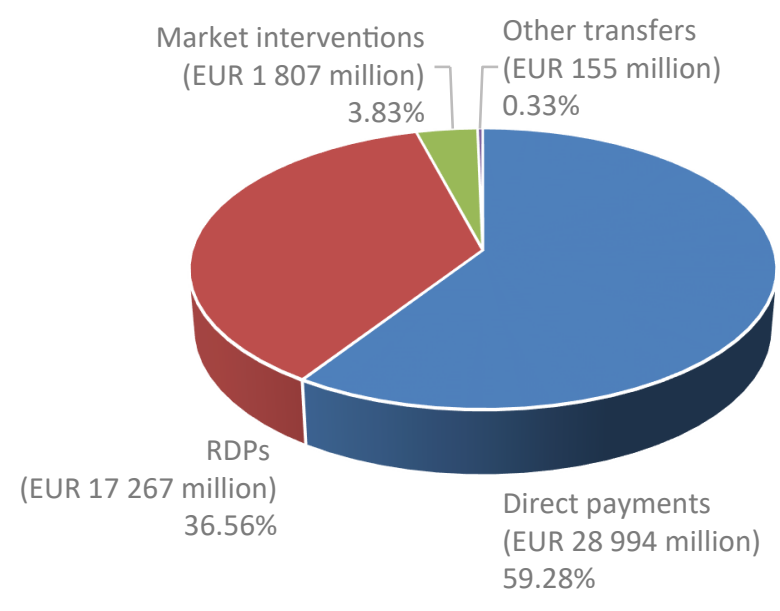

Fig. 4. Structure of CAP funds transferred from the EU budget to Poland in 2004-2017 (\%)

Source: own work based on data of the Polish Ministry of Finance.

high on the EU agenda. Supporting sustainable, quality employment is one of the priorities stressed in the European Structural and Investment Funds regulations 2014-2020. Yet, as it is being pointed out, "assessing the success or failure of the CAP in terms of job creation is not a simple matter, since the effects of the CAP on rural jobs are complex, and may work in opposite directions" (Davidova et al., 2016).

Poland's accession to the EU allowed the rural farming population to access the CAP instruments, including those intended to support farming incomes and the creation of new sources of non-agricultural rural incomes. In 2004-2017, Poland received EUR 47 billion under the CAP which accounts for over $30 \%$ of the total transfers from the EU budget. Almost $60 \%$ of CAP funds were transferred to the farmers as direct payments which became a vital income support instrument boosting demand in rural areas (Fig. 4).

The Rural Development Programs (RDPs) offer investment support which generates supply effects in the economy. RDPs enable non-agricultural job creation and income diversification for farming households. However, the analysis indicates that in 2002-2020, Poland spent relatively small portions of RDPs budgets for rural job creation and income diversification. By 2017, only 38 thousand projects were completed in this area (Table 1).

The financial perspective 2007-2013 was the first full 7-year budgetary framework Poland benefited from. One of the priority areas supported under RDP 2007 2013 was job creation and improvement of living conditions in rural areas (Axis 3 measures). In total, Poland allocated almost $20 \%$ the budget to this priority (including less than $6 \%$ to job creation). Measures focused on social capital building under Local Development Strategies (Axis 4 LEADER) "consumed" $4.5 \%$ of the RDP budget. Almost $75 \%$ of funds were spent on measures under Axis 1 and 2, primarily directed to the farmers.

Table 1. Rural jobs and income diversification in 2002-2020

\begin{tabular}{|c|c|c|c|}
\hline Program & Measure & $\begin{array}{l}\text { Completed } \\
\text { projects }\end{array}$ & $\begin{array}{l}\text { Share in total } \\
\text { payments }(\%)\end{array}$ \\
\hline $\begin{array}{l}\text { SAPARD } \\
(2002-2006)\end{array}$ & Diversification of economic activity & 4,071 & $6.75 \%$ \\
\hline $\begin{array}{l}\text { SOP Agriculture } \\
2004-2006\end{array}$ & $\begin{array}{l}\text { Diversification of income sources in farming } \\
\text { households }\end{array}$ & 4,015 & $6 \%$ \\
\hline \multirow[t]{2}{*}{ RDP 2007-2013 } & $\begin{array}{l}\text { Diversification towards non-agricultural } \\
\text { income }\end{array}$ & 15,718 & $1.85 \%$ \\
\hline & Creation and development of micro-businesses & 14,650 & $3.53 \%$ \\
\hline RDP 2014-2020 & $\begin{array}{l}\text { Non-agricultural activity and entrepreneurship } \\
\text { development (farming services) }\end{array}$ & $\mathrm{X}$ & $\begin{array}{c}3.5 \% \\
\text { (planned) }\end{array}$ \\
\hline
\end{tabular}

Source: own elaboration. 
The author's own research ${ }^{8}$ proves that CAP direct payments contribute to the preservation of jobs in agriculture. This, however, is only true for a limited group of rural residents. According to the Polish FADN data, in 2015 only some 150,000 farms reached the level of parity income. For most Polish farms, direct payments represent a form of social support. As shown by the survey (covering 150 family market-oriented farms) carried out as a part of the research, some $70 \%$ of the interviewees declared not to have any opportunity to undertake a non-agricultural economic activity 9

On top of pillar 1 measures, the farming community benefited the most from the RDP. As shown by the RDP 2007-2013 monitoring data, Poland spent EUR 1 billion (out of a total of EUR 17.2 billion) under Axis 3 on over 30,000 projects aimed at job creation (microbusinesses support) and income diversification for farming households. The analysis shows that the measure "Diversification towards non-agricultural income" resulted in creating 13.7 thousand (seasonal and permanent) jobs, $70 \%$ of which in the sector of agricultural and forestry services. As regards setting up and development of micro-businesses (most beneficiaries were natural persons registered as self-employed), over 24 thousand jobs were created (including 14.2 thousand directly linked to operations covered by support and 9.8 thousand indirectly related to EU-funded activities) (Sprawozdanie..., 2016, p. 58-59).

The RDP is the key public intervention offering preferential financing for rural jobs. However, considering the Polish population's needs in this area, the support is far too small. As shown by the analysis of RDP implementation, ca. EUR 70 million was dedicated to training and advisory support intended exclusively for farmers. This means neglecting the needs of the rural landless population who need new skills and qualifications to find quality employment outside the agriculture.

Because of planned CAP reforms and the expected EU funding constraints, the national public policy promoting the creation of rural jobs grows in importance. The Political Guidelines of Jean-Claude Juncker,

\footnotetext{
${ }^{8}$ See reference 2 .

${ }^{9}$ Those declaring to have such an option claim they can generate additional income from farming services (44.2\%) or offfarm services (transport, construction, agri-tourism $(7.2 \%)$ or trading (11.6\%)). However, for them, it was only an option and not a must.
}

President of the European Commission, presented in the European Parliament on July 15, 2014, include the following statement: "My first priority as Commission President will be to strengthen Europe's competitiveness and to stimulate investment for the purpose of job creation." The political guidelines were followed by the Investment Plan for Europe which calls for the mobilization of at least EUR 315 billion of additional investment over the next three years. The proposed actions are to be financed within the current Multi-Annual Financial Framework for the EU budget for 2014-2020. However, in order for this to happen, specific portions of the EU budget should be used in different ways, both at EU and national level: "The main idea is to provide greater risk-bearing capacity through public money in order to encourage project promoters and attract private finance to viable investment projects which would not have happened otherwise. This will make the best use of EU public resources" (European..., 2014).

In view of the above, when developing the rural entrepreneurship ecosystem, Poland shall focus on removing non-financial regulatory barriers; enhancing the business infrastructure by making information, training and an advisory network available to rural businesses, whether nascent or established; and making continued efforts to promote refundable financial instruments in the process of rural job creation. An access to external funds via financial instruments (including under the RDP) will enable a more efficient use of capital ${ }^{10}$ while limiting the deadweight effect.

\section{CONCLUSIONS}

The creation of non-agricultural jobs requires the adoption of an integrated policy approach offering a mix of aid instruments tuned to specific socio-economic conditions of rural areas. While job creation is not an explicit objective of the CAP, the second CAP pillar plays an important role by providing funding for activities focused on the diversification of income sources for farm households and the creation of non-agricultural jobs. The CAP backs the changes in institutional conditions, contributing to the creation of job opportunities through the development of human and social capital. Yet, this direct support is far from sufficient compared to the needs, especially considering the issue of excess labor

\footnotetext{
${ }^{10}$ Refundable funds have multiplier effects
} 
force in the agriculture sector. The CAP funds have strong demand and supply effects on the entire Polish economy, accompanied by various indirect effects in the area of job creation which cannot be neglected. Therefore, CAP assistance shall be seen in a broader context, as a stimulus for further private and public investments and a driver of the rural population's economic activity. Capturing those indirect effects was not the objective of this paper though.

The EU faces a strategic need of redefining the CAP goals to search for synergies with other EU and national public aid schemes for rural job creation. Dynamic technological changes around the world require a fundamental change in the global approach to addressing challenges posed by the decreasing demand for human work in the agriculture and industrial sectors (Naldi et al., 2015, p. 90-101). Poland shall build upon the experiences of RDP implementation and promote its own national programs strengthening the rural entrepreneurial ecosystem and rural business networks which allow to minimize the negative externalities of socio-economic growth in remote areas. As pointed by Myrdal, a "smart" and targeted state policy and the involvement of the private sector are necessary to overcome the accumulation of negative socio-economic developments (Myrdal, 1957, p. 23-24). The continued use of revolving financial instruments in the framework of the implementation of the CAP offers higher value for money (multiplier effect) and enables stronger synergies between EU programs, national development policies and private financial institutions. The government's role is to facilitate this process by establishing institutions and creating conditions (e.g. elimination of non-financial barriers) which stimulate economic activity in rural areas and drive an effective deployment of unused rural labor resources in non-agricultural sectors.

In 2004-2020, Poland remains the largest beneficiary of the EU budget under the second pillar. However, the funds dedicated to the promotion and diversification of rural economic activity continue to be relatively small. It is of utmost importance that these funds trigger synergies between different public aid programs designed to stimulate rural economic activity and strengthen the rural entrepreneurial ecosystem. Rural areas need further improvements to the institutional entrepreneurial support system in the search for synergies between various types of aid offered by the CAP, the EU Cohesion Policy and national aid schemes.

\section{SOURCE OF FINANCING}

Statutory donation Institute of Rural and Agricultural Development, Polish Academy of Sciences.

\section{REFERENCES}

Acemoglu, D., Johnson, S., Robinson, J. (2004). Institutions as the fundamental cause of long-run growth. NBER Working Paper 10481. Retrieved from: http://www.nber. org/papers/w10481

Benhabib, J., Spiegel, M. M. (1994). The Role of Human Capital in Economic Development: Evidence from Aggregate Cross-Country Data. J. Monet. Econ., 34, 143-173.

Copus, A. K., Hall, C., Barnes, A., Dalton, G., Cook, P., Weingarten, P., ..., Johansson, M. (2006). Study on Employment in Rural Areas (SERA). Final Deliverable. Retrieved from: https://www.researchgate.net/publication/228364830_Study_on_Employment_in_Rural_Areas_Final_Deliverable

Davidova, H., Hennessy, T., Thomson, K. (2016). Rural Jobs and the CAP: Spitting into the Wind? Retrieved from: http://ageconsearch.umn.edu/bitstream/236364/2/Sophia_ Davidova\%20upload.pdf

Dawkins, C. J. (2003). Regional Development Theory: Conceptual Foundations, Classic Works, and Recent Developments. J. Plan. Lit., 18(2). DOI: 10.1177/088541220 3254706.

Dimand, R. W., Spencer, J. B. (2008). Trevor Swan and the Neoclassical Growth Model, NBER Working Paper 13950. Retrieved from: http://www.nber.org/papers/w13950

European Commission (2014). An Investment Plan for Europe. $\mathrm{COM}(2014)$. Retrieved from: http://eur-lex.europa. eu/legal-content/EN/TXT/PDF/?uri=CELEX:52014DC0 $903 \&$ from $=$ EN

European Parliament (EP). Committee on Agriculture and Rural Development (2015). How can the CAP improve job creation in rural areas? Working Document AGRI DT(2015)573103 PE 573.103v01-00.

European Parliamentary Research Service (2016). Investing in regions to boost jobs. Cohesion policy and job creation, PE 593.490. DOI:10.2861/418532.

Fagerberg, J. (1994). Technology and International Differences in Growth Rates. J. Econ. Lit., 32(3), 1147-1175.

Farole, T., Rodríguez-Pose, A., Storper, M. (2009). Cohesion Policy in the European Union: Growth, Geography, Institutions. Report Working Paper of London School of Economics. Retrieved from: http://ec.europa.eu/regional_policy/archive/policy/future/pdf/6_pose_final-formatted.pdf 
Frenkel, I. (2016). Population of rural areas. In: J. Wilkin, I. Nurzyńska (Eds.), Rural Poland 2016. The report on the state of rural areas (pp. 17-51). Warszawa: FDPA, Wyd. Nauk. Scholar.

Halamska, M. (2013). Wiejska Polska na początku XXI wieku. Rozważania o gospodarce i społeczeństwie [Rural Poland at turn of XXI Century]. Warszawa: Wyd. Nauk. Scholar [in Polish].

Mankiw, N. G., Romer, D., Weil, D. N. (1992). A contribution to the Empirics of Economic Growth. Quart. J. Econ., 107, 407-437. Retrieved May 15 2016 from: http:// www.econ.nyu.edu/user/debraj/Courses/Readings/MankiwRomerWeil.pdf

Mankiw, N. G., Taylor, P. M. (2016). Makroekonomia. Warszawa: PWE [in Polish].

Myrdal, G. (1957). Economic Theory and Underdeveloped Regions. London: Duckworth.

Naldi, L., Nilsson, P., Westlund, H., Wixe, S. (2015). What is smart rural development? J. Rural Stud., 40, 90-101.

Nurzyńska, I. (2013). Oś 3. Jakość życia na obszarach wiejskich i różnicowanie gospodarki wiejskiej [Axis 3. Living conditions and rural economy diversification]. In: M. Zagórski (Ed.), Rozwój czy biurokracja? Ocena sposobu wdrażania PROW 2007-2013 [Growth or Red Tape? Evaluation of RDP 2007-2013 implementation]. Warszawa: EFRWP [in Polish].

Nurzyńska, I. (2016a). Polish rural areas and agriculture as beneficiaries of the European Union Funds. In: J. Wilkin, I. Nurzyńska (Eds.), Rural Poland 2016. The report on the state of rural areas (pp. 88-106). Warszawa: FDPA, Wyd. Nauk. Scholar.

Nurzyńska, I. (2016b). Przyczyny i przejawy peryferyjności obszarów wiejskich w Polsce [Causes and Symptoms of Peripherality in Rural Areas in Poland]. Wieś Roln., 2, 123-139 [in Polish].

Nurzyńska, I., Drygas, M., Goraj, L. (2017). System dopłat bezpośrednich Wspólnej Polityki Rolnej Unii Europejskiej. Rola, znaczenie i ewolucja [Direct Payments of the CAP in the European Union. Role, Importance and Evolution]. Raport $\mathrm{z}$ badań. Warszawa: EFRWP [in Polish].

Nurzyńska, I., Drygas, M., Kwieciński, J., Zagórski, M. (2011). Bariery instytucjonalne rozwoju przedsiębiorczości na obszarach wiejskich [Institutional barriers for the development of rural entrepreneurship]. Warszawa: EFRWP [in Polish]. Retrieved from: http://www.efrwp.pl/dir_upload/ download/thumb/773a24e764e9ef4a60a37a294933.pdf

Ploeg van der, J. (2008). The New Peasantries. Struggle for Autonomy and Sustainability in the Era of Empire and Globalization. London: Earthscan.

Polska wieś i rolnictwo. Prezentacja wyników badania (2015). [Polish Rural Areas and Agriculture. Report from the research]. Warszawa: MRiRW - ARiMR - ANR - KRUS - ARR [in Polish]. Retrieved from: https://bip.minrol. gov.pl/content/.../1/.../Polska\%20Wies\%20i\%20Rolnictwo_2015.pdf

Rodrik, D. (Ed.). (2003). In Search of Prosperity: Analytic Narratives on Economic Growth. Princeton: Princeton University Press.

Rodrik, D. (2007). One Economics, Many Recipes. Globalization, Institutions and Economic growth. Princeton: Princeton University Press.

Rodrik, D., Subramanian, A., Trebbi, F. (2002). Institutions rule: the primacy of institutions over geography and integration in economic development. NBER Working Paper 9305. Retrieved Aug 2016 from: http://www.nber.org/ papers/w9305

Romer, P. M. (1986). Increasing Returns and Long Run Growth. J. Polit. Econ., 94(5), 1002-1038.

Romer, P. M. (1989). Human Capital and Growth: Theory and Evidence. Working Paper No. 3173, NBER. Retrieved May $15^{\text {th }} 2016$ from: http://www.nber.org/papers/w3173

Solow, M. R. (1955). Technical Change and the Aggregate Production Function. Retrieved from: http://faculty. georgetown.edu/mh5/class/econ489/Solow-Growth-Accounting.pdf

Sprawozdanie z działalności Agencji Restrukturyzacji i Modernizacji Rolnictwa za 2015 rok (2016). [Annual Activity Report of Agency of Restructuring and Modernization of Agriculture 2015]. Warszawa: ARiMR [in Polish].

Wilkin, J. (Ed.). (2005). Teoria wyboru publicznego. Wstęp do ekonomicznej analizy polityki i funkcjonowania sfery publicznej [Public Choice Thoery. Introduction to Economic Analysis of Policy and Functioning of Public Sphere]. Warszawa: Wyd. Nauk. Scholar [in Polish]. 